\title{
ANALISIS DAMPAK BAURAN KEBIJAKAN MONETER DAN MAKROPRUDENSIAL TERHADAP STABILITAS HARGA DAN STABILITAS SISTEM KEUANGAN DI INDONESIA
}

\author{
Nisaulfathona Hidayati ${ }^{1}$, FX. Sugiyanto ${ }^{2}$ \\ Departemen IESP Fakultas Ekonomika dan Bisnis Universitas Diponegoro \\ nisaulfh@gmail.com
}

\begin{abstract}
The financial crisis that has happened has changed the perspective of the central banks in the world, including Indonesia in viewing that financial system stability is also important in addition to price stability. In achieving this goal, Bank Indonesia formulated a policy namely the Bank Indonesia Policy Mix which is the integration of monetary and macroprudential policies.

This research aims to analyze the impact of the monetary and macroprudential policy mix on price stability and financial system stability in Indonesia. The analysis method applied in this study is Vector Error Correction Model (VECM) and Granger Causality.

The results of the study show that both monetary and macroprudential policies can achieve price stability. In achieving financial system stability, monetary policy instruments take longer than macroprudential policies. The monetary and macroprudential policy mix instruments can reduce inflation volatility and exchange rate volatility so as to encourage price stability and financial system stability.
\end{abstract}

Keywords: SBI Rate, Base Money, Reserve Requirement-Primary-Secondary Foreign Currency, Loan to Value, VECM, Granger Casuality

JEL Classification: E-52, E-58

\section{PENDAHULUAN}

Bank sentral adalah lembaga keuangan sentral yang memiliki peran strategis dalam pengelolaan perekonomian suatu negara. Bank Indonesia sebagai bank sentral di Indonesia telah mengalami evolusi baik secara kelembagaan maupun peran, tugas dan tujuan. Seiring dengan perubahan waktu dan dinamika perekonomian, tujuan Bank Sentral dalam menjaga inflasi dianggap belum cukup untuk menjaga perekonomian dalam keadaan stabil dan terhindar dari krisis. Krisis keuangan yang pernah terjadi baik di Indonesia maupun global telah mengubah cara pandang terhadap mandat tunggal bank-bank sentral di dunia begitu juga Bank Indonesia bahwa stabilitas sistem keuangan juga penting dalam perekonomian suatu negara.

Indonesia sebagai negara dengan perekonomomian terbuka dimana dampak siklus bisnis global dapat berpengaruh ke inflasi melalui perubahan nilai tukar. Krisis keuangan akibat currency missmatch pada 1997/98 telah merusak perekonomian 
Indonesia dan mengakibatkan kebangkrutan perbankan. Melemahnya nilai tukar menjadi pemicu awal masalah likuiditas bagi perbankan.

Krisis keuangan tersebut juga merubah rezim nilai tukar yang sebelumnya tetap menjadi rezim nilai tukar mengambang, sehingga tingkat nilai tukar rupiah terhadap dollar menjadi fluktuatif berdasarkan tingkat permintaan dan penawaran di pasar valuta asing. Oleh karena itu, tingkat nilai tukar oleh otoritas moneter harus dijaga stabil karena nilai tukar yang tidak stabil khususnya yang mengalami depresiasi tajam dapat membawa implikasi krisis keuangan (Simorangkir, 2004).

Krisis selanjutnya yang menyebabkan keguncangan keuangan global adalah krisis 2008/09. Awal krisis tahun 2008 dengan kondisi suku bunga dan inflasi rendah mengakibatkan terjadinya peningkatan risiko yang diambil oleh bank secara umum melalui aktivitas pinjaman yang kemudian mendorong peningkatan risiko di sistem keuangan (Chen et al., 2016). Hal itu disebabkan oleh inovasi produk di sektor keuangan dengan banyaknya produk turunan (derivative) yang sulit dipahami oleh mekanisme transmisi kebijakan moneter (Warjiyo \& Juhro, 2016). Krisis tahun 2008 membuka pandangan banyak pihak bahwa stabilitas sistem keuangan juga penting disamping stabilitas harga karena ketidakstabilitan sistem keuangan dapat mempengaruhi stabilitas makroekonomi, meskipun tingkat inflasi rendah dan terjaga (International Monetary Fund, 2013).

Terlalu fokusnya bank sentral pada kebijakan moneter yang bertujuan menjaga stabilitas harga, menjadikan bank sentral kurang memperhatikan risiko yang timbul dari keterkaitan makroekonomi dengan sistem keuangan. Pengalaman atas krisis keuangan yang pernah terjadi menunjukkan bahwa keterkaitan sistem keuangan dengan makroekonomi (macro-financial linkages) sangat erat dan bahkan ketidakstabilan macro-financial tersebut yang menyebabkan timbulnya krisis (Warjiyo, 2010).

Sehingga, untuk menjaga risiko dari macro-financial dirumuskan suatu kebijakan yaitu kebijakan makroprudensial yang hadir untuk melengkapi kebijakan moneter yang tidak mampu dalam menjaga stabilitas sistem keuangan sendiri karena sebab dari ketidakstabilan keuangan tidak selalu berhubungan dengan tingkat likuiditas dalam sistem yang dapat diatasi oleh kebijakan moneter (International Monetary Fund, 2013).

Peran Bank Indonesia di bidang makroprudensial tertuang dalam UndangUndang (UU) Republik Indonesia No. 21 Tahun 2011 tanggal 22 November 2011 tentang Otoritas Jasa Keuangan (OJK), sejalan dengan beralihnya fungsi pengaturan dan pengawasan bank (mikroprudensial) ke Otoritas Jasa Keuangan (OJK). Dengan terbitnya Undang-Undang tersebut berarti Bank Indonesia kembali memiliki mandat ganda yaitu menjaga stabilitas rupiah dan mendukung stabilitas sistem keuangan dengan kebijakan yang ditempuh yaitu kebijakan moneter dan kebijakan makroprudensial.

Dengan hadirnya kebijakan makroprudensial, Bank Indonesia menyusun suatu integrasi kebijakan yang bernama Bauran Kebijakan Bank Indonesia. Bauran kebijakan yang disusun pada dasarnya adalah integrasi kebijakan moneter dan kebijakan makroprudensial untuk menjaga stabilitas rupiah dan stabilitas sistem keuangan yang mulai dilaksanakan pada tahun 2010 (Warjiyo, 2010). Selain Indonesia, telah ada beberapa negara yang mengintegrasikan kebijakan moneter dan 
kebijakan makroprudensial seperti Brazil, Israel, Korea, Polandia, Swedia, Turki, dan United States. Di Brazil, kebijakan moneter dan kebijakan makroprudensial (capital and reserve requirements) bekerja sama saat periode pasca krisis (2010-2011) untuk mengendalikan risiko dari pertumbuhan kredit yang cepat. Di Korea, fluktuasi harga perumahan berkorelasi kecil dengan inflasi dan fluktuasi tersebut dikendalikan dengan Loan To Value dan Debt to Income, sedangkan kebijakan moneter bank sentral digunakan untuk mencapai stabilitas output dan harga (International Monetary Fund, 2013). Negara lain yang juga telah mengadopsi policy mix adalah Turki sejak tahun 2010 yang didesain untuk mengatur volatilitas modal jangka pendek (Uysal, 2016).

Telah diterapkannya integrasi kebijakan moneter dan makroprudensial di beberapa negara tersebut, serta Bank Indonesia sendiri yang sudah menerapkan bauran kebijakan untuk mencapai sasaran akhir, maka pertanyaan penelitian ini dirumuskan sebagai berikut:

1. Bagaimana dampak masing-masing instrumen kebijakan moneter (SBI Rate, Uang Primer) dan kebijakan makroprudensial (GWM Primer, GWM Sekunder, GWM Valuta Asing, dan Loan To Value) terhadap stabilitas harga dan stabilitas sistem keuangan?

2. Bagaimana hubungan kausalitas antara instrumen bauran kebijakan Bank Indonesia dan sasaran akhir (stabilitas harga dan stabilitas sistem keuangan)?

\section{TINJAUAN PUSTAKA}

\section{Kerangka Dasar Hubungan Antara Kebijakan Moneter dan Kebijakan Makroprudensial}

Kebijakan moneter dan makroprudensial beroperasi di bawah paradigma yang sama, yakni paradigma countercyclical. Kebijakan moneter fokus pada stabilitas harga, sedangkan kebijakan makroprudensial fokus pada stabilitas keuangan. Kedua kebijakan ini saling terkait satu sama lain.

Gambar 1. Integrasi Kerangka Kebijakan Moneter dan Makroprudensial

\begin{tabular}{|c|c|c|c|c|}
\hline $\begin{array}{l}\text { MONETARY POLICY } \\
\text { - Interest and Exchange } \\
\text { Rate } \\
\text { - Open Market Operation } \\
\text { - Reserve Requirement } \\
\text { Management of Foreign } \\
\text { Capital Flows } \\
\text { Coordination- } \\
\text { Communication }\end{array}$ & $\begin{array}{l}\text { FINANCIAL SYSTEMAS } \\
\text { MONETARY } \\
\text { TRANSMISSION } \\
\text { - Interest Rate } \\
\text { - Liquidity and Money } \\
\text { Supply } \\
\text { - Credit } \\
\text { - Risk Behavior }\end{array}$ & $\begin{array}{l}\text { MACROECONOI } \\
\text { ANALYSIS AND } \\
\text { FORECAST } \\
\text { - Macroeconom } \\
\text { Inflation, } \\
\text { Rate, CA d } \\
\text { fiscal } \\
\text { - Forecast and F } \\
\text { - Policy Scenari }\end{array}$ & $\begin{array}{l}\text { DP, } \\
\text { nge } \\
\text { and }\end{array}$ & $\begin{array}{l}\text { ULTIMATE } \\
\text { TARGET: } \\
\text { PRICE STABILITY } \\
\text { - Inflation Target } \\
\text { - Consider Exchange } \\
\text { Rate Stability, CA } \\
\text { Deficit, GDP } \\
\text { growth }\end{array}$ \\
\hline $\begin{array}{l}\text { MACROPRUDENTIAL } \\
\underline{\text { POLICY }} \\
\text { - } \quad \text { Loan-to-value (LTV) } \\
\text { - } \quad \text { Counter-cyclical } \\
\text { buffer } \\
-\quad \text { Other instruments } \\
\end{array}$ & $\begin{array}{l}\text { MACRO-FINANCIAL AN } \\
\text { FORECAST } \\
\text { - Macro-financial analys } \\
\text { forecast and risk } \\
\text { - Procyclicality study: cr } \\
\text { external debts, capital f } \\
\text { - Systemic Risk Assesn } \\
\text { financial network }\end{array}$ & $\begin{array}{l}\text { SAND } \\
\text { financial system: } \\
\text {, housing bubbles, } \\
\text { terconnection and }\end{array}$ & \multicolumn{2}{|c|}{$\begin{array}{l}\text { ULTIMATE TARGET: } \\
\text { SUPPORT FINANCIAL SYSTEM } \\
\text { STABILITY } \\
\text { - Procyclicality and Systemic } \\
\text { Risk are maintained } \\
\text { Coordination within Financial } \\
\text { Stability System Comittee to } \\
\text { support Financial System } \\
\text { Stability }\end{array}$} \\
\hline
\end{tabular}

Sumber: (Warjiyo, 2010) 
Kondisi makroekonomi yang merupakan hasil dari implementasi kebijakan moneter, akan secara langsung memengaruhi stabilitas sistem keuangan. Perlambatan ekonomi atau volatilitas nilai tukar, misalnya, dapat secara langsung berdampak pada kinerja penyaluran dan kualitas kredit perbankan (Bank Indonesia, 2016).

Berdasarkan gambar 4.1, kebijakan moneter dan kebijakan makroprudensial ditransmisikan bersama ke sistem keuangan kemudian ke sasaran akhir dengan mempertimbangkan analisis dan prakiraan makroekonomi serta makro-finansial untuk kemudian dapat mencapai sasaran akhir Bank Indonesia yaitu stabilitas harga dan mendukung stabilitas sistem keuangan.

\section{Kebijakan Moneter}

Menurut Mishkin (2010), kebijakan moneter adalah kebijakan bank sentral atau otoritas moneter dalam bentuk pengendalian besaran moneter dan/atau suku bunga untuk mencapai tujuan perekonomian yang diinginkan. Dalam mengatur jumlah uang beredar, instrumen yang umum digunakan di berbagai negara adalah cadangan wajib minimum, discount rate, dan operasi pasar terbuka.

\section{Stabilitas Harga}

Tugas Bank Indonesia dalam menjaga stabilitas harga tercantum dalam UU No. 23 Tahun 1999 untuk mencapai dan memelihara kestabilan rupiah. Stabilitas harga dicerminkan dengan stabilitas inflasi. Kestabilan inflasi merupakan prasyarat bagi pertumbuhan ekonomi yang berkesinambungan yang pada akhirnya memberikan manfaat bagi peningkatan kesejahteraan masyarakat.

\section{Risiko Sistemik}

(FSB, BIS, \& IMF, 2009) mendefinisikan risiko sistemik sebagai risiko gangguan terhadap jasa keuangan yang disebabkan oleh memburuknya semua atau sebagian dari sistem keuangan yang mempunyai potensi dampak negatif serius terhadap perekonomian riil.

\section{Prosiklikalitas}

Berdasarkan Financial Stability Board (2009), prosiklikalitas berkaitan dengan interaksi dinamis antara sektor keuangan dan sektor riil di perekonomian. Prosiklisitas menunjukkan fenomena dimana siklus keuangan mengakselerasi siklus ekonomi yang disebabkan oleh faktor-faktor baik dari sisi mikro sektor keuangan maupun sisi makroekonomi.

\section{Kebijakan Makroprudensial}

International Monetary Fund (IMF), mendefinisikan kebijakan makroprudensial adalah kebijakan yang memiliki tujuan utama untuk memelihara stabilitas sistem keuangan secara keseluruhan melalui pembatasan peningkatan risiko sistemik.

Berdasarkan IMF Financial Stability and Macroprudential Policy Survey (2010), Instrumen kebijakan makroprudensial dikelompokkan berdasarkan masalah yang dapat timbul dalam sistem keuangan yang dapat berpengaruh pada stabilitas sistem keuangan yaitu masalah kredit, likuiditas, dan modal. Instrumen yang 
digunakan dalam mengatasi masalah kredit adalah Caps on the loan-to-value (LTV) ratio, Caps on the debt-to-income (DTI) ratio, Caps on foreign currency lending, dan Ceiling on credit or credit growth. Untuk masalah likuiditas, instrumen yang digunakan adalah Limits on net open currency positions/currency missmatch (NOP), Limits on maturity mismatch, dan Reserve Requirement. Kemudian, untuk masalah modal instrumen yang digunakan adalah Countercyclical/time-varying capital requirements, Time varying/dynamic provisioning, dan Restrictions on profit distribution.

\section{Stabilitas Sistem Keuangan}

Stabilitas sistem keuangan belum memiliki definisi yang seragam secara internasional. Bank for International Settlements (BIS) dan Financial Stability Forum mendefinisikan ketidakstabilan sistem keuangan adalah situasi dimana kinerja ekonomi berpotensi memburuk akibat fluktuasi harga aset keuangan atau ketidakmampuan institusi keuangan untuk memenuhi kewajibannya. UndangUndang No. 9 Tahun 2016 tentang Pencegahan dan Penanganan Krisis Sistem Keuangan (UU-PPSK) yaitu kondisi sistem keuangan yang berfungsi efektif dan efisien serta mampu bertahan dari gejolak yang bersumber dari dalam negeri dan luar.

\section{Bauran Kebijakan}

Kebijakan moneter dalam small-open economy di bawah kondisi harga komoditas global yang bergejolak dan arus modal sangatlah kompleks. Dalam keadaan seperti itu, kebijakan suku bunga saja tidak efektif sebagai instrumen untuk memenuhi sasaran stabilitas harga, dan tidak dapat menjaga stabilitas makroekonomi dan sistem keuangan secara keseluruhan. Gabungan antara ukuran kebijakan moneter dan makroprudensial diperlukan untuk menghadapi berbagai tantangan "impossible trinity" dan menjaga stabilitas sistem moneter dan keuangan (Warjiyo, 2012). Krisis keuangan global memperkuat keyakinan bahwa menjaga kestabilan harga sebagai tujuan utama kebijakan moneter tetap relevan meskipun tidak cukup untuk menjaga stabilitas makroekonomi. Beberapa negara juga telah melaksanakan kebijakan moneter dan makroprudensial yang "work in tandem".

\section{Penelitian Terdahulu}

Kajian dan penelitian spesifik mengenai Bauran Kebijakan Moneter dan Makroprudensial belum banyak karena pemahaman mengenai bauran kebijakan yang belum dipahami dan disepakati oleh banyak pihak. Penelitian spesifik mengenai Bauran Kebijakan di Indonesia telah dilakukan pertama kali dan satu-satunya hingga sekarang oleh Wimanda, Maryaningsih, Nurliana, \& Satyanugroho (2014). Penelitian yang telah banyak dilakukan adalah mengenai transmisi kebijakan moneter, sedangkan kajian mengenai kebijakan makroprudensial terus dikembangkan agar makin banyak pihak yang memahami mengenai kebijakan ini.

Penelitian Wimanda et al (2014) dengan judul Evaluasi Transmisi Bauran Kebijakan di Indonesia menunjukkan hasil penelitian bahwa kebijakan moneter dengan BI Rate mampu mempengaruhi inflasi dan ISSK. Pengetatan kebijakan makroprudensial mampu mempengaruhi nilai tukar tetapi tidak efektif terhadap 
inflasi. Penelitian oleh Wimanda, Permata, Bathaluddin, \& Wibowo (2012) dengan judul penelitian Studi Kebijakan Makroprudensial di Indonesia: Evaluasi dan Analisa Integrasi Kebijakan Bank Indonesia menggunakan variabel GWM, GWM LDR, 1MHP, 6MHP, NOP, LTV dengan metode VARX. Hasil penelitian yang didapat adalah tingkat volatilitas nilai tukar menurun setelah penerapan 1MHP, 6MHP, dan NOP. Akinci \& Olmstead-rumsey (2015) melakukan penelitian untuk melihat efektivitas kebijakan makropudensial dengan penelitian berjudul How Effective are Macroprudential Policies menunjukkan bahwa hanya kebijakan makroprudensial yang berkaitan dengan perumahan (LTV dan DTI) yang dapat membatasi pertumbuhan kredit perumahan dan inflasi harga rumah. Dumičić (2017) melakukan penelitian berjudul Effectiveness of Macroprudential Policies in Central and Eastern European Countries dengan hasil penelitian ini adalah instrumen makroprudensial berhasil menurunkan pertumbuhan kredit sektor perumahan.

Uysal (2016) melakukan penelitian dengan studi kasus Turki yang telah menerapkan bauran kebijakan moneter dan makroprudensial menunjukkan hasil bahwa bahwa gabungan kedua kebijakan tersebut mampu membantu menguatkan stabilitas harga, keuangan, dan makroekonomi. Purnawan \& Nasir (2015) melakukan penelitian untuk melihat peran kebijakan makroprudensial dalam mengontrol volatilitas nilai tukar, likuiditas, dan kredit bank. Hasil penelitian menunjukkan bahwa tingkat volatilitas nilai tukar menurun setelah penerapan periode $1 \mathrm{MHP}$ dan $6 \mathrm{MHP}$ enam bulan dalam kebijakan kurs mengambang, namun untuk nilai tukar nominal kebijakan ini tidak efektif.

\section{METODE PENELITIAN}

Data yang digunakan dalam penelitian ini adalah data sekunder yang berasal dari Bank Indonesia dan Badan Pusat Statistik. Data yang digunakan merupakan data time series secara kuartal dari tahun 2005:Q1 hingga 2017:Q4.

\section{Variabel Instrumen Bauran Kebijakan Bank Indonesia}

Variabel instrumen bauran kebijakan terdiri dari variabel instrumen kebijakan moneter dan instrumen kebijakan makroprudensial. Instrumen bauran kebijakan yang digunakan dalam penelitian ini adalah:

\section{A. Variabel Instrumen Kebijakan Moneter}

\section{A.1. Suku Bunga Sertifikat Bank Indonesia}

Pengukuran instrumen kebijakan moneter dengan suku bunga SBI dikarenakan suku bunga SBI lebih dinamis yang terbentuk dari proses lelang setiap minggunya. Dalam penelitian ini suku bunga SBI dinotasikan sebagai SBI Rate.I

\section{A.2. Uang Primer}

Definisi uang primer menurut Bank Indonesia adalah kewajiban bank sentral (BI) kepada bank umum, Bank Perkreditan Rakyat (BPR), dan sektor swasta (tidak termasuk Pemerintah Pusat dan luar negeri). Dalam penelitian ini uang primer dinotasikan dengan M0. 


\section{B. Variabel Instrumen Kebijakan Makroprudensial B.1. Giro Wajib Minimum (GWM)}

Giro wajib minimum yang sebelumnya lebih dikenal sebagai instrumen moneter juga digunakan untuk mencegah risiko sistemik dan menjaga stabilitas sistem keuangan dalam siklus kegiatan ekonomi. Instrumen kebijakan GWM juga tidak difokuskan pada upaya untuk menangani risiko yang terjadi pada individual bank, sehingga instrumen kebijakan tersebut dapat dikategorikan sebagai instrumen kebijakan dalam perspektif 'makroprudensial' yang lebih luas (Warjiyo \& Juhro, 2016). GWM yang digunakan dalam penelitian ini terdiri atas 3 jenis, yaitu GWM Primer, GWM Sekunder, dan GWM Valuta Asing yang dinotasikan dengan GWMP, GWMS, dan GWMValas.

\section{B.2 Loan To Value (LTV) Ratio}

Menurut Bank Indonesia, Loan To Value Ratio adalah angka rasio antara nilai kredit yang dapat diberikan oleh bank terhadap nilai agunan berupa properti pada saat pemberian kredit berdasarkan hasil penilaian terkini.

\section{Variabel Stabilitas Harga \\ - Inflasi}

Inflasi dinyatakan menggunakan Indeks Harga Konsumen dan perubahan IHK merupakan gambaran atas perubahan inflasi. Untuk mengukur stabilitas harga menggunakan volatilitas inflasi yang dihitung dengan standar deviasi dari perubahan inflasi. Dalam penelitian ini, inflasi dinotasikan sebagai INF.

\section{Variabel Stabilitas Sistem Keuangan}

- Nilai tukar

Berbeda halnya dengan indikator stabilitas harga yang sudah disepakati secara internasional dengan indeks harga, stabilitas keuangan belum memiliki pengukuran yang tepat tentang definisi operasional stabilitas keuangan yang tepat dan sesuai (Park, 2011). Penelitian ini menggunakan stabilitas nilai tukar yang juga merupakan indikator stabilitas moneter sebagai indikator stabilitas sistem keuangan karena berdasarkan studi literatur dan pengalaman empiris yang telah ada, keguncangan nilai tukar dapat mengakibatkan ketidakstabilan sektor-sektor keuangan dan menjadi muara dari masalah-masalah ekonomi lainnya.

Pengalaman krisis tahun 1998 yang berawal dari krisis nilai tukar akibat tingginya depresiasi rupiah menyebabkan terjadinya currency missmatch membawa implikasi ke sisi moneter dan makroekonomi. Penelitian ini menggunakan variabel nilai tukar rupiah terhadap dollar sebagai indikator stabilitas sistem keuangan berdasarkan studi literatur dan pengalaman empiris yang telah ada bahwa keguncangan nilai tukar dapat berpengaruh terhadap stabilitas sektor-sektor keuangan dan stabilitas makroekonomi, sebagai berikut:

1. Depresiasi rupiah dapat menyebabkan tekanan currency missmatch semakin besar. Currency missmatch tidak hanya meningkatkan kesempatan terjadinya finansial krisis tetapi juga dapat meningkatkan biaya (Goldstein \& Turner, 2004). Depresiasi rupiah dapat meningkatkan harga dari sisi penawaran (cost-push inflation) karena struktur industri Indonesia masih bergantung dari bahan baku impor. Ketika biaya produksi naik dengan asumsi profit perusahaan tidak 
mengalami perubahan, maka kenaikan biaya produksi akan dibebankan pada harga jual produk sehingga harga menjadi naik.

2. Kurs sebagai bagian dari stabilitas moneter yang apabila tidak stabil dapat mempengaruhi dunia usaha dan perbankan. Jika perusahaan atau dunia usaha collapse akan mengganggu rasio kecukupan modal (Capital Adequacy Ratio/CAR) dan Non Performing Loan/NPL perbankan. Perusahaan tak sanggup lagi membayar cicilan kredit bank, sehingga menyebabkan kenaikan kredit macet dan mempengaruhi likuiditas perbankan.

3. Kurs selain dianggap sebagai alat tukar juga dianggap sebagai aset yang masuk ke industri keuangan. Mata uang dianggap sebagai aset sehingga apabila kurs rupiah terhadap dollar mengalami depresiasi, masyarakat akan cenderung memegang mata uang dollar dan dapat menyebabkan kurs rupiah semakin mengalami depresiasi. Pelaku di pasar valuta asing merasakan peluang bahwa mereka dapat menghasilkan keuntungan besar jika mereka bertaruh pada depresiasi mata uang (Mishkin, 2013). Mata uang yang ditetapkan terhadap dolar AS menjadi sasaran serangan spekulatif, di mana spekulan terlibat dalam penjualan mata uang secara besar-besaran. Ketika penjualan mata uang membanjiri pasar, pasokan jauh melebihi permintaan, nilai mata uang runtuh, dan krisis mata uang terjadi (Mishkin, 2013). Kurs rupiah yang terus mengalami depresiasi dapat mengakibatkan kepanikan investor akan kondisi domestik di Indonesia dan investor dapat menarik uangnya dari Indonesia. Sehingga, depresiasi nilai tukar mempengaruhi stabilitas pasar uang dan pada akhirnya dapat mempengaruhi stabilitas sistem keuangan.

4. Kurs yang tidak stabil dan mengalami depresiasi tajam dapat meningkatkan beban hutang bagi pemerintah, perusahaan, dan lembaga keuangan yang memiliki hutang luar negeri. Memburuknya neraca bank dan ketidakseimbangan fiskal yang parah adalah dua faktor utama yang memicu serangan spekulatif dan menceburkan ekonomi ke dalam skala penuh, goncangan buruk dari krisis mata uang dan krisis keuangan dapat mengakibatkan kehancuran (Mishkin, 2013).

5. Pasar valuta asing di negara ekonomi berkembang umumnya belum berfungsi dengan baik dan efisien karena kejutan ekonomi domestik dan aliran modal asing sehingga menyebabkan fluktuasi nilai tukar yang tinggi. Perkembangan nilai tukar berdampak terhadap inflasi secara langsung melalui harga barang-barang impor dan tidak langsung melalui permintaan domestik. Fluktuasi nilai tukar juga berdampak pada terjaganya SSK melalui pengaruhnya terhadap neraca lembaga keuangan maupun perkembangan harga saham dan yield obligasi (Warjiyo \& Juhro, 2016)

6. Pasca krisis keuangan global 2008/09 volatilitas nilai tukar di berbagai negara semakin meningkat yang dapat menimbulkan tekanan pada stabilitas moneter dan stabilitas sistem keuangan, sehingga volatilitas nilai tukar perlu diperhatikan oleh bank sentral (Warjiyo \& Juhro, 2016)

Untuk mengukur stabilitas nilai tukar menggunakan volatilitas nilai tukar yang dihitung dengan standar deviasi dari perubahan nilai tukar. Dalam penelitian ini, nilai tukar dinotasikan dengan Exchange Rate yang disingkat ER. 


\section{Vector Error Correction Model (VECM)}

Vector Auto Regression atau VAR merupakan salah satu metode time-series yang sering digunakan dalam penelitian terutama di bidang ekonomi. Apabila model VAR tidak stasioner di tingkat level dan berkointegrasi maka akan dikombinasikan dengan model koreksi Vector Error Correction Model (VECM).

Jika model VAR dapat ditulis sebagai berikut:

$$
Z_{t}=\sum_{i=1}^{k} \Pi_{1} Z_{t-i}+u_{t}
$$

Maka estimasi VECM berdasarkan persamaan (3.1) dalam bentuk firstdifference seperti berikut:

$$
\Delta Z t=\Pi_{i} Z_{t-i}+\sum_{i=1}^{k-1} \Gamma_{\mathrm{i}} \Delta \mathrm{Z}_{\mathrm{t}-1}+\mathrm{u}_{\mathrm{t}}
$$

Model empiris untuk dampak bauran kebijakan terhadap stabilitas harga dinamakan persamaan inflasi sebagai berikut:

$\mathrm{INF}_{\mathrm{t}}=\mathrm{a}_{0}+\mathrm{a}_{1}$ SBI Rate $\mathrm{S}_{\mathrm{t}}+\mathrm{a}_{2} \operatorname{logBM} \mathrm{t}_{\mathrm{t}}+\mathrm{a}_{3} \mathrm{GWMP}_{\mathrm{t}}+\mathrm{a}_{4} \mathrm{GWMS}_{\mathrm{t}}+\mathrm{a}_{5} \mathrm{GWMValas}_{\mathrm{t}}+$ $\mathrm{a}_{6} \mathrm{LTV}_{\mathrm{t}}+\mathrm{u}_{1 \mathrm{t}}$

Model empiris untuk dampak bauran kebijakan terhadap stabilitas sistem keuangan dinamakan persamaan nilai tukar sebagai berikut:

$\mathrm{ER}_{\mathrm{t}}=\mathrm{a}_{10}+\mathrm{a}_{11}$ SBI Rate R $_{\mathrm{t}}+\mathrm{a}_{12} \operatorname{logBM}_{\mathrm{t}}+\mathrm{a}_{13}$ GWMP $_{\mathrm{t}}+\mathrm{a}_{14}$ GWMS $_{\mathrm{t}}+\mathrm{a}_{15}$ GWMValas $_{\mathrm{t}}+\mathrm{a}_{16}$ LTV $_{\mathrm{t}}+\mathrm{u}_{2 \mathrm{t}}$ berikut:

Persamaan (3.3) dituliskan dengan model VAR pada persamaan (3.1) sebagai

SBIRate $_{t}=\alpha_{0}+\sum_{i=1}^{k} \alpha_{1}$ aSBIRate $_{t-i}+\sum_{i=1}^{k} \alpha_{2} \log M 0_{t-i}+\sum_{i=1}^{k} \alpha_{3} G W M P_{t-i}+$ $\sum_{i=1}^{k} \alpha_{4} G W M S_{t-i}+\sum_{i=1}^{k} \alpha_{5}$ GWMValas $_{t-i}+\sum_{i=1}^{k} \alpha_{6}$ LTV $_{t-i}+\sum_{i=1}^{k} \alpha_{7} I N F_{t-i}+u_{1 t}$

$\log M 0_{t}=\alpha_{10}+\sum_{i=1}^{k} \alpha_{11}$ aSBIRate $_{t-i}+\sum_{i=1}^{k} \alpha_{12} \log M 0_{t-i}+\sum_{i=1}^{k} \alpha_{13} G W M P_{t-i}+$ $\sum_{i=1}^{k} \alpha_{14} G W M S_{t-i}+\sum_{i=1}^{k} \alpha_{15}$ GWMValas $_{t-i}+\sum_{i=1}^{k} \alpha_{16}$ LTV $_{t-i}+\sum_{i=1}^{k} \alpha_{17} I N F_{t-i}+u_{2 t}$

$G W M P_{t}=\alpha_{20}+\sum_{i=1}^{k} \alpha_{21}$ aSBIRate $_{t-i}+\sum_{i=1}^{k} \alpha_{22} \log M 0_{t-i}+\sum_{i=1}^{k} \alpha_{23} G W M P_{t-i}+$ $\sum_{i=1}^{k} \alpha_{24} G_{W M} S_{t-i}+\sum_{i=1}^{k} \alpha_{25}$ GWMValas $_{t-i}+\sum_{i=1}^{k} \alpha_{26}$ LTV $_{t-i}+\sum_{i=1}^{k} \alpha_{27} I N F_{t-i}+u_{3 t}$

$G W M S_{t}=\alpha_{30}+\sum_{i=1}^{k} \alpha_{31}$ aSBIRate $_{t-i}+\sum_{i=1}^{k} \alpha_{32} \log M 0_{t-i}+\sum_{i=1}^{k} \alpha_{33} G W M P_{t-i}+$ $\sum_{i=1}^{k} \alpha_{34} G_{W M} S_{t-i}+\sum_{i=1}^{k} \alpha_{35}$ GWMValas $_{t-i}+\sum_{i=1}^{k} \alpha_{36}$ LTV $_{t-i}+\sum_{i=1}^{k} \alpha_{37} I N F_{t-i}+u_{4 t}$ 
GWMValas $_{t}=\alpha_{40}+\sum_{i=1}^{k} \alpha_{41}$ aSBIRate $_{t-i}+\sum_{i=1}^{k} \alpha_{42} \log M 0_{t-i}+\sum_{i=1}^{k} \alpha_{43} G W M P_{t-i}+$ $\sum_{i=1}^{k} \alpha_{44} G W M S_{t-i}+\sum_{i=1}^{k} \alpha_{45} G_{W}$ MValas $_{t-i}+\sum_{i=1}^{k} \alpha_{46} L_{T V}+i+\sum_{i=1}^{k} \alpha_{47} I N F_{t-i}+u_{5 t}$

$L T V_{t}=\alpha_{50}+\sum_{i=1}^{k} \alpha_{51}$ aSBIRate $_{t-i}+\sum_{i=1}^{k} \alpha_{52} \log M 0_{t-i}+\sum_{i=1}^{k} \alpha_{53} G W M P_{t-i}+$ $\sum_{i=1}^{k} \alpha_{54} G W M S_{t-i}+\sum_{i=1}^{k} \alpha_{55}$ GWMValas $_{t-i}+\sum_{i=1}^{k} \alpha_{56}$ LTV $_{t-i}+\sum_{i=1}^{k} \alpha_{57} I_{N F_{t-i}}+u_{6 t}$

$I N F_{t}=\alpha_{60}+\sum_{i=1}^{k} \alpha_{61} a_{\text {SBIRate }}+i+\sum_{i=1}^{k} \alpha_{62} \log M 0_{t-i}+\sum_{i=1}^{k} \alpha_{63} G W M P_{t-i}+$ $\sum_{i=1}^{k} \alpha_{64} G W M S_{t-i}+\sum_{i=1}^{k} \alpha_{65}$ GWMValas $_{t-i}+\sum_{i=1}^{k} \alpha_{66}$ LTV $_{t-i}+\sum_{i=1}^{k} \alpha_{67} I N F_{t-i}+u_{7 t}$

Persamaan (3.4) dapat dituliskan spesifikasi model VAR sesuai persamaan (3.1) sebagai berikut:

SBIRate $_{t}=\alpha_{70}+\sum_{i=1}^{k} \alpha_{71}$ aSBIRate $_{t-i}+\sum_{i=1}^{k} \alpha_{72} \log$ S $_{t-i}+\sum_{i=1}^{k} \alpha_{73} G W M P_{t-i}+$ $\sum_{i=1}^{k} \alpha_{74} G W M S_{t-i}+\sum_{i=1}^{k} \alpha_{75} G_{W M V V_{\text {alas }}-i}+\sum_{i=1}^{k} \alpha_{76} L T V_{t-i}+\sum_{i=1}^{k} \alpha_{77} E R_{t-i}+u_{8 t}$

$\operatorname{lnM} 0_{t}=\alpha_{80}+\sum_{i=1}^{k} \alpha_{81}$ aSBIRate t $-i+\sum_{i=1}^{k} \alpha_{82} \log M 0_{t-i}+\sum_{i=1}^{k} \alpha_{83} G W M P_{t-i}+$ $\sum_{i=1}^{k} \alpha_{84} G W M S_{t-i}+\sum_{i=1}^{k} \alpha_{85} G_{W M V V^{2} a s_{t-i}}+\sum_{i=1}^{k} \alpha_{86} L T V_{t-i}+\sum_{i=1}^{k} \alpha_{87} E_{t-i}+u_{9 t}$

$G W M P_{t}=\alpha_{90}+\sum_{i=1}^{k} \alpha_{91}$ aSBIRate $_{t-i}+\sum_{i=1}^{k} \alpha_{92} \log M 0_{t-i}+\sum_{i=1}^{k} \alpha_{93} G W M P_{t-i}+$ $\sum_{i=1}^{k} \alpha_{94} G W M S_{t-i}+\sum_{i=1}^{k} \alpha_{95} G_{W}$ MValas $_{t-i}+\sum_{i=1}^{k} \alpha_{96} L_{T V}+i+\sum_{i=1}^{k} \alpha_{97} E R_{t-i}+u_{10 t}$

$G W M S_{t}=\alpha_{100}+\sum_{i=1}^{k} \alpha_{101}$ aSBIRate $_{t-i}+\sum_{i=1}^{k} \alpha_{102} \log M 0_{t-i}+\sum_{i=1}^{k} \alpha_{103} G W M P_{t-i}+$ $\sum_{i=1}^{k} \alpha_{104} G W M S_{t-i}+\sum_{i=1}^{k} \alpha_{105}$ GWMValas $_{t-i}+\sum_{i=1}^{k} \alpha_{106}$ LTV $_{t-i}+\sum_{i=1}^{k} \alpha_{107} E_{t-i}+u_{11 t}$

GWMValas $_{t}=\alpha_{110}+\sum_{i=1}^{k} \alpha_{111}$ aSBIRate $_{t-i}+\sum_{i=1}^{k} \alpha_{112} \log M 0_{t-i}+\sum_{i=1}^{k} \alpha_{113} G W M P_{t-i}+$ $\sum_{i=1}^{k} \alpha_{114} G W M S_{t-i}+\sum_{i=1}^{k} \alpha_{115} G_{W M V a l a s} t-i+\sum_{i=1}^{k} \alpha_{116} L T V_{t-i}+\sum_{i=1}^{k} \alpha_{117} E R_{t-i}+u_{12 t}$

$L T V_{t}=\alpha_{120}+\sum_{i=1}^{k} \alpha_{121}$ aSBIRate $e_{t-i}+\sum_{i=1}^{k} \alpha_{122} \log M 0_{t-i}+\sum_{i=1}^{k} \alpha_{123} G W M P_{t-i}+$ $\sum_{i=1}^{k} \alpha_{124} G W M S_{t-i}+\sum_{i=1}^{k} \alpha_{125}$ GWMValas $_{t-i}+\sum_{i=1}^{k} \alpha_{126}$ LTV $_{t-i}+\sum_{i=1}^{k} \alpha_{127} E_{t-i}+u_{13 t}$

$E R_{t}=\alpha_{130}+\sum_{i=1}^{k} \alpha_{131}$ aSBIRate $_{t-i}+\sum_{i=1}^{k} \alpha_{132} \log M 0_{t-i}+\sum_{i=1}^{k} \alpha_{133} G W M P_{t-i}+$ $\sum_{i=1}^{k} \alpha_{134} G W M S_{t-i}+\sum_{i=1}^{k} \alpha_{135} G_{W W V a l a s}-i+\sum_{i=1}^{k} \alpha_{136} L T V_{t-i}+\sum_{i=1}^{k} \alpha_{137} I N F_{t-i}+u_{14 t}$

Tujuan VECM adalah mengoreksi disequilibrium jangka pendek terhadap jangka panjangnya. Sehingga, dari model VAR diatas dipilih persamaan (3.11) dan (3.18) agar sesuai dengan tujuan penelitian. Persamaan (3.11) dan (3.18) ditransformasikan menjadi model VECM pada persamaan (3.2) yang menjadi model dalam penelitian ini sebagai berikut: 
$\Delta I N F_{t}=\alpha_{0}+\sum_{i=1}^{k} \alpha_{1} \Delta S B$ Rate $_{t-i}+\sum_{i=1}^{k} \alpha_{2} \Delta \log B M_{t-i}+\sum_{i=1}^{k} \alpha_{3} \Delta G W M P_{t-i}+$ $\sum_{i=1}^{k} \alpha_{4} \Delta G W M S_{t-i}+\sum_{i=1}^{k} \alpha_{5} \Delta G W$ MValas $_{t-i}+\sum_{i=1}^{k} \alpha_{6} \Delta L T V_{t-i}+\sum_{i=1}^{k} \alpha_{7} \Delta I N F_{t-i}+u_{1 t}$

$\Delta E R_{t}=\alpha_{1}+\sum_{i=1}^{k} \alpha_{11} \Delta$ SBIRate $_{t-i}+\sum_{i=1}^{k} \alpha_{12} \Delta \ln B M_{t-i}+\sum_{i=1}^{k} \alpha_{13} \Delta G W M P_{t-i}+$ $\sum_{i=1}^{k} \alpha_{14} \Delta G W M S_{t-i}+\sum_{i=1}^{k} \alpha_{15} \Delta G W$ MValas $_{t-i}+\sum_{i=1}^{k} \alpha_{16} \Delta L T V_{t-i}+\sum_{i=1}^{k} \alpha_{17} \Delta E R_{t-i}+u_{2 t}$

\section{HASIL DAN PEMBAHASAN}

Respon Kebijakan SBI Rate terhadap Stabilitas Harga dan Stabilitas Sistem Keuangan

\section{A. Analisis VECM}

Dalam jangka panjang, instrumen kebijakan SBI Rate memiliki hubungan negatif signifikan terhadap volatilitas inflasi. Kenaikan suku bunga SBI direspon dengan penurunan volatilitas inflasi secara signifikan sehingga mendorong stabilitas harga. Hasil ini sejalan dengan penelitian Amrini, Aimon, \& Syofyan (2012) bahwa kenaikan suku bunga SBI akan menurunkan inflasi karena menarik minat masyarakat untuk menyimpan uangnya dalam bentuk SBI karena mengharapkan pengembalian yang lebih tinggi. Oleh karena itu, peningkatan suku bunga SBI akan diikuti oleh berkurangnya jumlah uang beredar dan pada akhirnya menurunkan inflasi. Sedangkan dalam jangka pendek hubungan antara suku bunga SBI dan volatilitas inflasi tidak signifikan.

Tabel 1. Hasil VECM SBI Rate

\begin{tabular}{ccc} 
& Volatilitas Inflasi & \\
Variabel & Jangka Panjang & \\
KBIRate (-1) & $-0.202581^{*}$ & t-statistik parsial \\
& Jangka Pendek & -8.13121 \\
D(SBIRATE(-1)) & -0.063110 & -0.40186 \\
D(SBIRATE(-2)) & -0.155141 & -0.96547 \\
D(SBIRATE(-3)) & -0.174075 & -0.97694 \\
& Volatilitas Nilai Tukar & \\
Variabel & Jangka Panjang & \\
SBIRATE(-1) & Koefisien & t-statistik parsial \\
& $-949.2658^{*}$ & -5.28025 \\
D(SBIRATE(-1)) & Jangka Pendek & \\
D(SBIRATE(-2)) & 59.92604 & 1.13340 \\
D(SBIRATE(-3)) & 63.89708 & 1.25907 \\
\hline
\end{tabular}

Keterangan: $\mathrm{t}$ kritis $* 0,05=2,01537 ; * * 0,10=1,68023$

Dalam jangka panjang, instrumen kebijakan suku bunga SBI memiliki hubungan negatif terhadap volatilitas nilai tukar secara signifikan. Kebijakan suku bunga SBI secara signifikan menurunkan volatilitas nilai tukar. Kenaikan suku bunga SBI dapat menurunkan volatilitas nilai tukar sehingga mendorong sistem keuangan yang stabil. Hasil ini sejalan dengan sejalan dengan penelitian Purnawan \& Nasir 
(2015), Wimanda et al (2012), dan Wimanda et al (2014) bahwa kebijakan suku bunga SBI dapat menurunkan volatilitas nilai tukar dan mendorong apresiasi rupiah kemudian pada akhirnya mendorong stabilitas sistem keuangan. Sedangkan dalam jangka pendek, perubahan suku bunga kebijakan tidak direspon secara signifikan oleh volatilitas nilai tukar.

\section{B. Analisis Impulse Response Function (IRF)}

Perubahan kebijakan suku bunga SBI belum direspon oleh inflasi pada kuartal 1 hingga 4. Kebijakan SBI mulai direspon oleh inflasi pada kuartal ke-empat dengan volatilitas yang bergejolak tinggi hingga kuartal ke-11. Volatilitas inflasi mulai menurun pada kuartal ke-16 ditandai dengan impulse response yang tidak bergejolak secara tajam hal ini berarti inflasi tidak lagi sangat bergejolak seperti periode sebelumnya dan volatilitas inflasi mulai stabil dan mencapai keseimbangan pada kuartal ke-23.

Gambar 2. Impulse Response terhadap SBI Rate
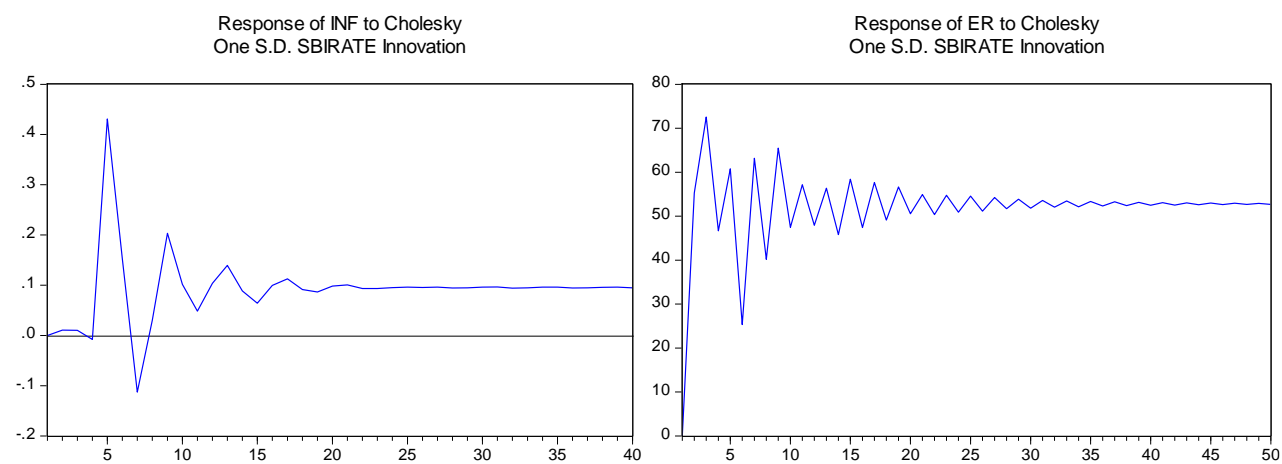

Guncangan kebijakan suku bunga SBI mulai direspon oleh nilai tukar pada periode ketiga dengan pergerakan volatilitas yang ekstrim dan tinggi. Volatilitas mulai menurun sejak kuartal ke-23 hingga jangka panjang volatilitas mulai mengecil. Meskipun volatilitas menurun, guncangan kebijakan suku bunga SBI belum mampu membawa nilai tukar dalam kondisi stabil hingga kuartal ke-42, volatilitas inflasi mencapai keseimbangan

\section{Respon Kebijakan Uang Primer terhadap Stabilitas Harga dan Stabilitas Sistem Keuangan}

\section{A. Analisis VECM}

Dalam jangka panjang, kebijakan uang primer memiliki hubungan positif terhadap volatilitas inflasi secara signifikan. Kenaikan dalam jumlah uang primer akan meningkatkan volatilitas inflasi sehingga menurunkan stabilitas harga. Sedangkan dalam jangka pendek, kebijakan uang primer tidak berpengaruh secara signifikan terhadap stabilitas harga. Sedangkan terhadap volatilitas nilai tukar, kebijakan uang primer tidak memiliki hubungan secara signifikan. 
Tabel 2. Hasil VECM Uang Primer

\begin{tabular}{ccc} 
& Volatilitas Inflasi & \\
Jangka Panjang & \\
Koefisien & t-statistik parsial \\
LNBM(-1) & $6.629143^{*}$ & 9.80333 \\
Jangka Pendek & \\
D(LOGBM(-1)) & 4.214829 & 0.66736 \\
D(LOGBM(-2)) & 3.937873 & 0.5171 \\
D(LOGBM(-3)) & -1.78889 & -0.30935 \\
& Volatilitas Nilai Tukar & \\
Variabel & Jangka Panjang & \\
LOGBM(-1) & Koefisien & t-statistik parsial \\
& -7112.237 & -1.42946 \\
D(LOGBM(-1)) & Jangka Pendek & -0.01670 \\
D(LOGBM(-2)) & -32.20958 & -1.36159 \\
D(LOGBM(-3)) & -2985.904 & -1.39130 \\
\hline Keterangan & -2662.806 & \\
\hline
\end{tabular}

Keterangan: $\mathrm{t}$ kritis $* 0,05=2,01537 ; * * 0,10=1,68023$

\section{B. Analisis Impulse Response Function (IRF)}

Shock kebijakan uang primer direspon oleh inflasi pada kuartal kedua dengan volatilitas inflasi yang tinggi hingga periode ke-12. Volatilitas inflasi mulai menurun dan tidak begitu tajam pada periode ke-20 dan volatilitas inflasi mulai stabil pada periode ke-35. Volatilitas inflasi yang stabil menandakan bahwa nominal inflasi juga stabil.

Shock kebijakan uang primer langsung direspon oleh volatilitas nilai tukar pada kuartal pertama dengan gejolak yang ekstrem. Mulai kuartal ke-25, volatilitas mulai menurun dan tidak besar tetapi belum stabil karena hasil impulse response masih naik turun. Volatilitas nilai tukar mulai stabil pada kuartal ke-45.

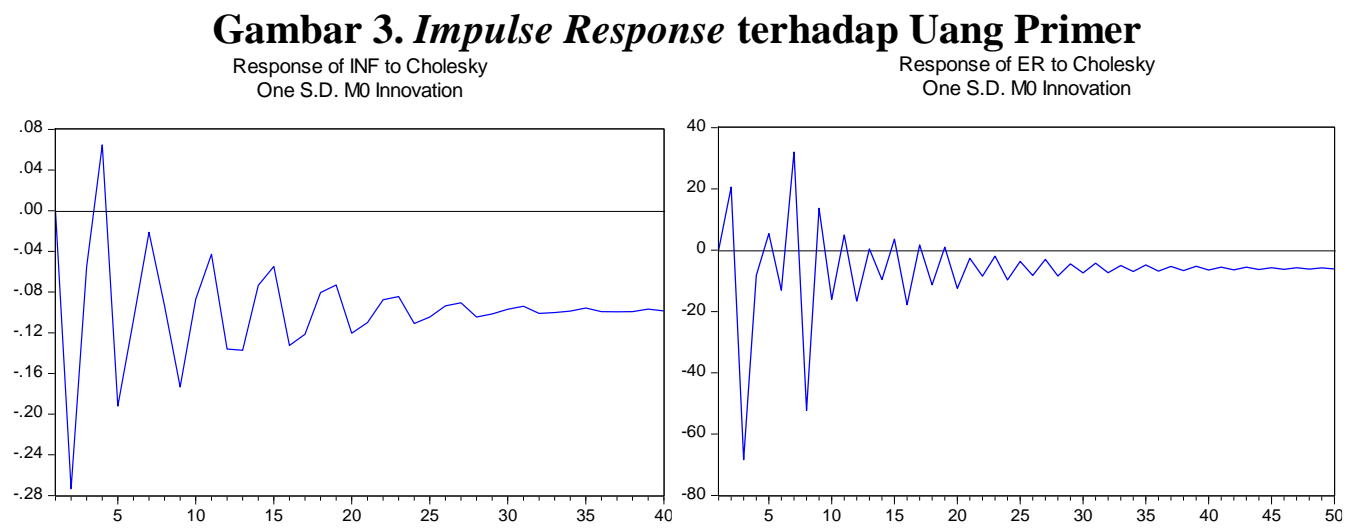




\section{Respon Kebijakan Giro Wajib Minimum (GWM) Primer terhadap Stabilitas Harga dan Stabilitas Sistem Keuangan}

\section{A. Analisis VECM}

Dalam jangka panjang, kebijakan GWM primer memiliki hubungan positif terhadap volatilitas inflasi secara signifikan. Kenaikan dalam ketetapan GWM primer akan meningkatkan volatilitas inflasi. Dalam jangka pendek, kebijakan GWM Primer juga berpengaruh secara positif signifikan pada lag 1 dan lag 2. Kenaikan ketetapan GWM Primer pada 1 tahun sebelumnya akan meningkatkan volatilitas inflasi sebesar 0,97\% pada tahun sekarang dan kenaikan ketetapan GWM Primer pada 2 tahun sebelumnya akan meningkatkan volatilitas inflasi sebesar $1,15 \%$.

Kondisi ini tidak sesuai dengan teori yang ada bahwa cadangan wajib minimum memiliki hubungan yang negatif terhadap inflasi. Penentuan besaran cadangan wajib minimum yang tepat akan berdampak terhadap pengendalian inflasi. Hasil penelitian ini sejalan dengan Purnawan \& Nasir (2015) dan Wimanda et al (2012) bahwa kondisi ini tidak terlepas dari besarnya ekses likuiditas yang telah ada di sektor perbankan serta arus masuk modal asing yang juga sangat besar. Sehingga, kenaikan kebijakan GWM Primer relatif tidak berpengaruh banyak terhadap pengurangan ekses likuiditas.

Tabel 3. Hasil VECM GWM Primer

\begin{tabular}{ccc} 
& Volatilitas Inflasi & \\
Jangka Panjang & \\
Koefisien & t-statistik parsial \\
GWM_P(-1) & $0.499245^{*}$ & 11.6392 \\
& Jangka Pendek & \\
D(GWM_P(-1)) & $0.978823^{*}$ & 2.39290 \\
D(GWM_P(-2)) & $1.151027^{*}$ & 2.21900 \\
D(GWM_P(-3)) & 0.468201 & 1.09798 \\
& Volatilitas Nilai Tukar & \\
Jangka Panjang & t-statistik parsial \\
GWM_P(-1) & Koefisien & -7.19190 \\
& $-2237.836^{*}$ & 0.96228 \\
D(GWM_P(-1)) & Jangka Pendek & $1.1351]$ \\
D(GWM_P(-2)) & 109.6324 & -0.15961 \\
D(GWM_P(-3)) & 176.0086 & \\
\hline
\end{tabular}

Keterangan: $\mathrm{t}$ kritis $* 0,05=2,01537 ; * * 0,10=1,68023$

Dalam jangka panjang, dampak kebijakan GWM primer berhubungan signifikan dan negatif terhadap volatilitas nilai tukar. Kenaikan ketetapan kebijakan GWM primer diiringi dengan penurunan volatilitas nilai tukar. GWM Primer berpengaruh negatif signifikan terhadap nilai tukar berarti ketika GWM Primer diturunkan maka nilai tukar rupiah per dollar naik yang artinya rupiah depresiasi. GWM Primer diturunkan maka jumlah uang beredar akan meningkat, sehingga menurunkan nilai rupiah dan mendorong inflasi. Inflasi pada akhirnya dapat 
menyebabkan nilai tukar menjadi depresiasi sesuai teori paritas daya beli. Sedangkan ketika GWM Primer dinaikkan, dapat mengontrol volatilitas nilai tukar menjadi menurun sehingga rupiah apresiasi.

\section{B. Analisis Impulse Response Function (IRF)}

Shock kebijakan GWM Primer mulai direspon oleh inflasi pada kuartal ke-2 dengan volatilitas yang besar hingga kuartal ke-12 dan mulai mengecil hingga kuartal ke-20. Volatilitas inflasi mulai stabil pada kuartal ke-22 yang menandakan bahwa stabilitas harga dapat tercapai.

Respon volatilitas nilai tukar terhadap shock kebijakan GWM Primer terhadap langsung direspon pada awal periode. Volatilitas nilai tukar tinggi hingga kuartal 10 dan mulai mengecil hingga kuartal ke-16. Pada kuartal ke-28, volatilitas nilai tukar mulai stabil, yang berarti bahwa stabilitas nilai tukar dapat tercapai yang kemudian dapat mendorong stabilitas sistem keuangan.

Gambar 4. Impulse Response terhadap GWM Primer

Response of INF to Cholesky $\quad$ Response of ER to Cholesky

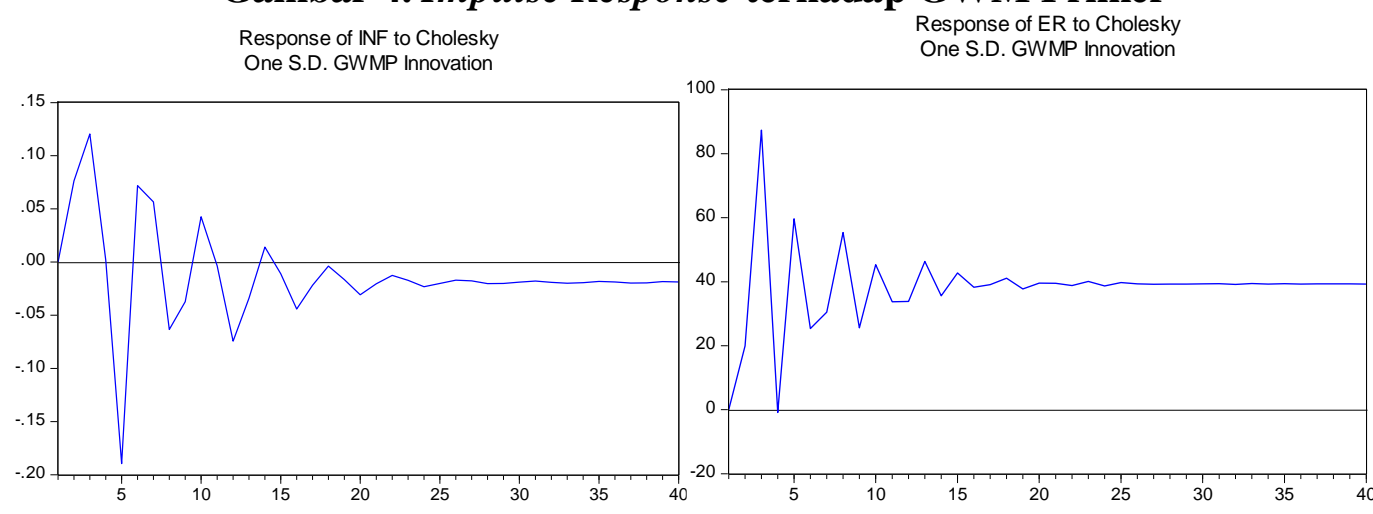

\section{Respon Kebijakan GWM Sekunder terhadap Stabilitas Harga dan Stabilitas Sistem Keuangan}

\section{A. Analisis VECM}

Dalam jangka panjang, kebijakan GWM sekunder memiliki hubungan negatif terhadap volatilitas inflasi secara signifikan. Kenaikan dalam ketetapan GWM primer akan diiringi dengan penurunan volatilitas inflasi secara signifikan. GWM Sekunder merupakan cadangan wajib bank umum yang wajib dipelihara pada sertifikat Bank Indonesia dan/atau surat berharga negara. Ketika ketetapan GWM Sekunder dinaikkan, maka bank umum wajib menempatkan cadangan di sertifikat Bank Indonesia lebih tinggi menyebabkan likuiditas menurun dan inflasi dapat dikendalikan. Sedangkan dalam jangka panjang, kebijakan GWM sekunder tidak memiliki hubungan dengan volatilitas inflasi secara signifikan. 
Tabel 4. Hasil VECM GWM Sekunder

\begin{tabular}{ccc} 
Variabel & $\begin{array}{c}\text { Volatilitas Inflasi } \\
\text { Jangka Panjang } \\
\text { Koefisien }\end{array}$ & t-statistik parsial \\
GWM_S(-1) & $-0.925667^{*}$ & -12.8051 \\
& Jangka Pendek & \\
D(GWM_S(-1)) & -1.06161 & -1.46310 \\
D(GWM_S(-2) & -1.31144 & -1.49585 \\
D(GWM_S(-3)) & -0.51936 & -0.71909 \\
& Volatilitas Nilai Tukar & \\
Jangka Panjang & t-statistik parsial \\
GWM_S(-1) & Koefisien & 2.85588 \\
D(GWM_S(-1)) & $1561.930 *$ & -1.08719 \\
D(GWM_S(-2)) & Jangka Pendek & -0.85200 \\
D(GWM_S(-3)) & -235.7066 & -1.19718 \\
\hline Keteriabel & -229.2039 &
\end{tabular}

Keterangan: $\mathrm{t}$ kritis $* 0,05=2,01537 ; * * 0,10=1,68023$

Dalam jangka panjang, dampak kebijakan GWM sekunder berhubungan positif signifikan terhadap volatilitas nilai tukar. Sedangkan dalam jangka pendek, tidak memiliki hubungan secara signifikan. Kenaikan ketetapan GWM sekunder diiringi dengan volatilitas nilai tukar menjadi meningkat pada jangka panjang.

\section{B. Analisis Impulse Response Function (IRF)}

Shock kebijakan GWM sekunder direspon secara tajam oleh volatilitas inflasi pada kuartal pertama hingga kuartal ke-12. Kemudian, volatilitas inflasi mulai menurun tidak bergejolak secara tajam dan stabil pada kuartal ke-29.

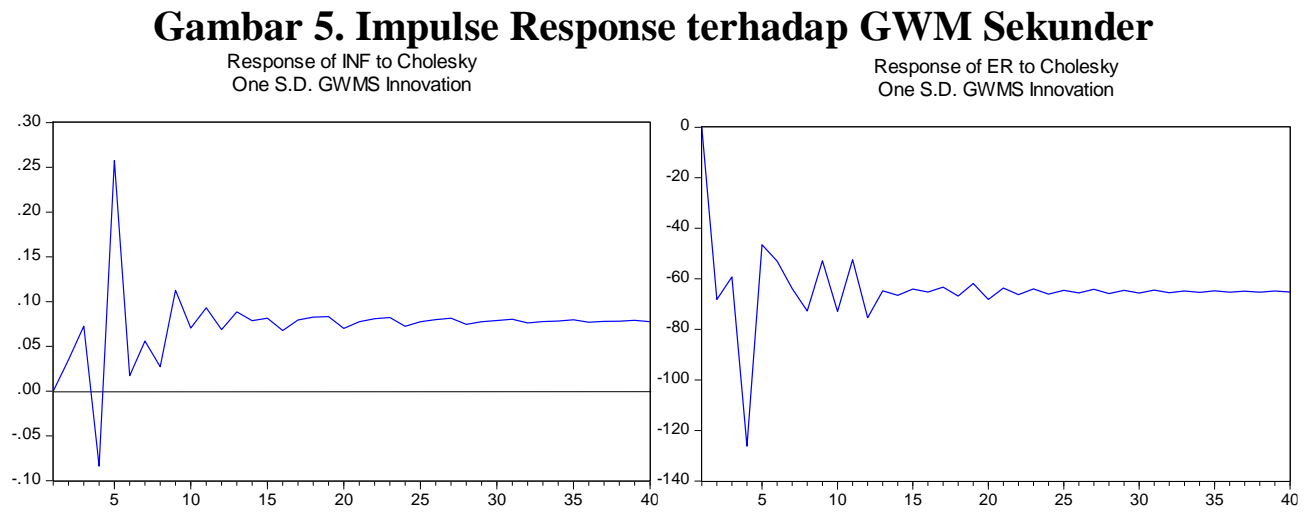

Shock kebijakan GWM sekunder langsung direspon oleh volatilitas nilai tukar sejak awaal hingga kuartal ke-12 dengan volatilitas inflasi yang esktrem. Volatilitas mulai menurun pada kuartal ke-13 hingga 24 meskipun belum stabil. Volatilitas inflasi mulai stabil pada kuartal ke-34. 


\section{Respon Kebijakan GWM Valuta Asing terhadap Stabilitas Harga dan Stabilitas} Sistem Keuangan

\section{A. Analisis VECM}

Peningkatan arus masuk modal asing telah mengakibatkan peningkatan kondisi likuiditas valuta asing perbankan secara signifikan. Arus masuk modal asing tersebut lebih bersifat jangka pendek dan berdampak pada kondisi ekses likuiditas valuta asing yang dapat menyebabkan instabilitas nilai tukar dan gangguan pada stabilitas ekonomi makro. Oleh karena itu, kebijakan GWM Valuta Asing dinaikkan agar dapat mendorong bank mempunyai manajemen yang baik dalam mengatur likuiditas valas.

Dalam jangka panjang, kebijakan GWM valas berhubungan negatif terhadap volatilitas inflasi secara signifikan. Kenaikan dalam ketetapan GWM valas akan menurunkan volatilitas inflasi. Dalam jangka pendek, kebijakan GWM valas juga memiliki hubungan negatif dan signifikan pada lag 1 dan lag 3. Kenaikan ketetapan GWM valas pada 1 tahun sebelumnya akan menurunkan volatilitas inflasi sebesar 1,38\% pada tahun sekarang dan kenaikan ketetapan GWM valas pada 3 tahun sebelumnya akan menurunkan volatilitas inflasi sebesar $1,11 \%$. Ketika kebijakan GWM valas dinaikkan maka perbankan wajib memelihara likuiditas valas lebih tinggi sehingga kredit dalam bentuk valas juga turun.

Tabel 5. Hasil VECM GWM Valas

\begin{tabular}{ccc} 
& Volatilitas Inflasi & \\
Jangka Panjang & \\
Kariabel & Koefisien & t-statistik parsial \\
GWM_VALAS(-1) & $-0.842097^{*}$ & -12.4465 \\
& Jangka Pendek & \\
D(GWM_VALAS(-1)) & $-1.38133^{*}$ & -2.24287 \\
D(GWM_VALAS(-2)) & -0.39779 & -0.89221 \\
D(GWM_VALAS(-3)) & $-1.10801^{*}$ & -2.48925 \\
& Volatilitas Nilai Tukar & \\
Variabel & Jangka Panjang & t-statistik parsial \\
GWM_VALAS(-1) & Koefisien & 10.9189 \\
& $5565.697^{*}$ & -0.49808 \\
D(GWM_VALAS(-1)) & Jangka Pendek & 0.22326 \\
D(GWM_VALAS(-2)) & -109.8446 & -0.37235 \\
D(GWM_VALAS(-3)) & 28.62528 & \\
\hline Keterangan:t & -92.73813 &
\end{tabular}

Keterangan: $\mathrm{t}$ kritis $* 0,05=2,01537 ; * * 0,10=1,68023$

Dalam jangka panjang, dampak kebijakan GWM Valas berhubungan positif signifikan terhadap volatilitas nilai tukar. Sedangkan dalam jangka pendek, tidak memiliki pengaruh secara signifikan. Depresiasinya nilai tukar terhadap kenaikan kebijakan GWM Valas tidak terlepas dari besarnya ekses likuiditas yang telah ada di sektor perbankan serta arus masuk modal asing yang juga sangat besar. Hasil ini sejalan dengan penelitian Purnawan \& Nasir (2015) dan Wimanda et al (2012). 


\section{B. Analisis Impulse Response Function (IRF)}

Shock kebijakan GWM valas mulai direspon oleh volatilitas inflasi pada kuartal ke-2 hingga kuartal ke-17 dengan volatilitas yang besar. Volatilitas inflasi mulai stabil pada periode ke-18 yang menunjukkan bahwa volatilitas inflasi menurun dari periode sebelumnya dan kembali pada keseimbangan pada kuartal ke-33.

\section{Gambar 6. Impulse Response terhadap GWM Valas}

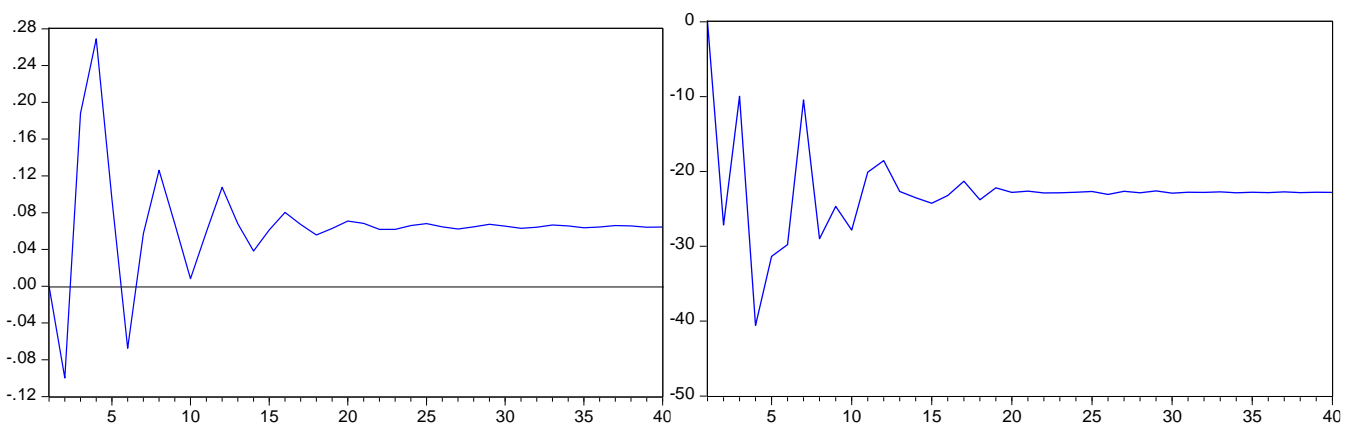

Shock kebijakan GWM Valas direspon oleh volatilitas nilai tukar yang besar. Volatilitas nilai tukar bergejolak tajam hingga kuartal ke-17 dan mulai stabil pada kuartal ke-21 yang berarti bahwa stabilitas nilai tukar dapat tercapai yang kemudian dapat mendorong stabilitas sistem keuangan.

\section{Respon Kebijakan Loan to Value (LTV) terhadap Stabilitas Harga dan Stabilitas Sistem Keuangan}

\section{A. Analisis VECM}

Dalam jangka panjang, kebijakan LTV berhubungan positif terhadap volatilitas inflasi secara signifikan. Pelonggaran LTV berarti bahwa bank umum dapat meningkatkan pemberian kredit untuk sektor perumahan lebih sehingga kredit yang beredar akan meningkat. Begitu juga ketika LTV diketatkan maka inflasi turun karena pertumbuhan kredit menurun, hal ini sejalan dengan penelitian Wimanda et al (2014) dan Wimanda et al (2012). Penelitian ini juga sesuai dengan teori klasik, bahwa inflasi disebabkan karena terlalu banyaknya uang beredar atau terlalu banyak kredit dibandingkan volume transaksi, begitu juga sebaliknya. Sedangkan dalam jangka pendek, pengaruh LTV terhadap volatilitas inflasi tidak signifikan.

Tabel 6. Hasil VECM Loan to Value

\begin{tabular}{lcc} 
Variabel & $\begin{array}{c}\text { Volatilitas Inflasi } \\
\text { Jangka Panjang } \\
\text { Koefisien }\end{array}$ & t-statistik parsial \\
LTV $(-1)$ & $0.036380^{*}$ & 7.05789 \\
& Jangka Pendek & \\
D(LTV $(-1))$ & -0.01428 & -0.87858 \\
D $($ LTV $(-2))$ & -0.01249 & -0.75980 \\
D(LTV $(-3))$ & -0.01148 & -0.70548 \\
& Volatilitas Nilai Tukar & \\
\hline
\end{tabular}




\section{Variabel \\ $\operatorname{LTV}(-1)$}

$\mathrm{D}(\operatorname{LTV}(-1))$

$\mathrm{D}(\operatorname{LTV}(-2))$

D(LTV(-3))
Jangka Panjang

Koefisien

$-471.1601^{*}$

Jangka Pendek

2.106861

$-2.720475$

$-3.229882$

\section{t-statistik parsial}

$-12.1225$

0.41586

$-0.54203$

$-0.65428$

Keterangan: t kritis $* 0,05=2,01537 ; * * 0,10=1,68023$

Dalam jangka panjang, dampak kebijakan LTV memiliki hubungan negatif signifikan terhadap volatilitas nilai tukar. Sedangkan dalam jangka pendek, tidak memiliki pengaruh secara signifikan. Ketika kebijakan LTV dinaikkan atau dilonggarkan, maka nilai tukar rupiah akan mengalami apresiasi. Hal ini dapat disebabkan karena terdapat kebijakan lain diluar LTV yaitu suku bunga untuk mengatur nilai tukar. Dalam menjaga nilai tukar, Bank Indonesia meningkatkan suku bunga acuannya tetapi kenaikan suku bunga acuan dapat meningkatkan suku bunga yang lain termasuk suku bunga kredit sehingga dapat menurunkan pertumbuhan kredit sektor perumahan sehingga diimbangi dengan relaksasi kebijakan LTV untuk mendorong sektor perumahan (Bank Indonesia, 2018).

\section{B. Analisis Impulse Response Function (IRF)}

Respon volatilitas inflasi terhadap shock kebijakan LTV mulai direspon pada kuartal ke-2 dengan volatilitas yang tinggi. Pada kuartal ke-15, volatilitas mulai menurun yang berarti volatilitas inflasi lebih kecil daripada periode sebelumnya. Volatilitas inflasi kembali pada keseimbangan pada kuartal ke-27.

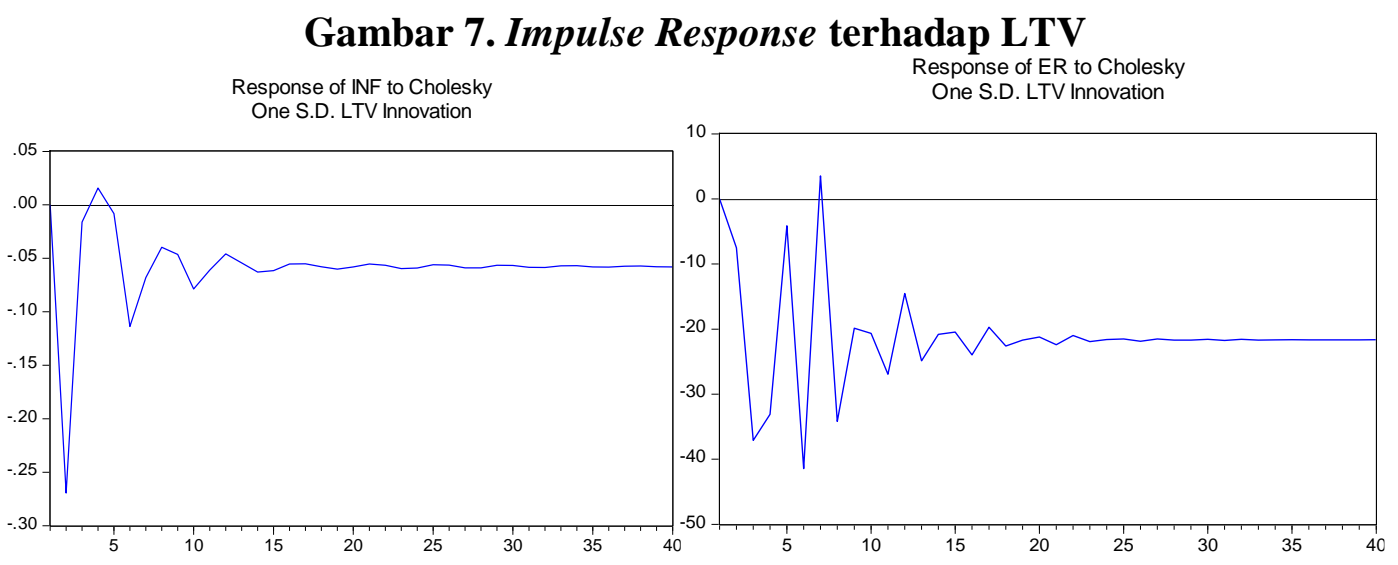

Shock kebijakan LTV direspon oleh nilai tukar dengan volatilitas yang naikturun secara tajam hingga kuartal 8. Volatilitas mulai menurun sejak kuartal 9 hingga 17. Volatilitas nilai tukar kembali ke keseimbangan pada kuartal ke-24 yang berarti stabilitas nilai tukar tercapai.

\section{Uji Granger Casuality}

Uji granger casuality digunakan untuk melihat kausalitas antara masingmasing variabel. Dalam uji ini, seluruh variabel digabungkan untuk melihat hubungan kausalitas antar variabel. Volatilitas inflasi dan volatilitas nilai tukar 
diubah menjadi inflasi dan nilai tukar untuk melihat hubungan kausalitas antara inflasi dan nilai tukar mendasarkan teori Purchasing Power Parity (PPP). Teori PPP menjelaskan perbandingan nilai suatu mata uang ditentukan oleh daya beli uang tersebut terhadap barang dan jasa di masing-masing negara.

Panjang lag yang digunakan adalah 4 (empat) sesuai nilai terendah pada kriteria yang digunakan yaitu Likehood Ratio (LR), Final Prediction Error (FPE), Akaike Information Criterion (AIC), Schwarz Information Criterion (SC), dan Hannan-Quin Criterion (HQ). Jika nilai F-Statistik lebih besar dari nilai F kritis pada tingkat signifikansi lima persen, maka null hypotesis ditolak artinya terdapat pengaruh antar variabel.

Tabel 7. Hasil Granger Casuality yang Memiliki Hubungan Kausalitas

\begin{tabular}{lcll}
\multicolumn{1}{c}{ Null Hypothesis } & F-statistic & Prob & \multicolumn{1}{c}{ Hasil Uji } \\
GWMP does not Granger Cause INF & 3.27422 & 0.0208 & H0 ditolak \\
INF does not Granger Cause GWMP & 0.70704 & 0.5920 & H0 tidak ditolak \\
GWMS does not Granger Cause INF & 3.74413 & 0.0113 & H0 ditolak \\
INF does not Granger Cause GWMS & 0.69701 & 0.5986 & H0 tidak ditolak \\
LOGBM does not Granger Cause ER & 2.09753 & 0.0996 & H0 tidak ditolak \\
ER does not Granger Cause LOGBM & 2.98691 & 0.0304 & H0 ditolak \\
GWMP does not Granger Cause LOGBM & 2.97746 & 0.0308 & H0 ditolak \\
LOGBM does not Granger Cause GWMP & 1.93828 & 0.1234 & H0 tidak ditolak \\
GWMS does not Granger Cause LOGBM & 4.38455 & 0.0050 & H0 ditolak \\
LOGBM does not Granger Cause GWMS & 4.15183 & 0.0068 & H0 ditolak \\
GWMVALAS does not Granger Cause LOGBM & 0.51232 & 0.7270 & H0 tidak ditolak \\
LOGBM does not Granger Cause GWMVALAS & 2.60287 & 0.0506 & H0 ditolak \\
GWMVALAS does not Granger Cause GWMP & 0.47835 & 0.7514 & H0 tidak ditolak \\
GWMP does not Granger Cause GWMVALAS & 2.86629 & 0.0357 & H0 ditolak \\
\hline
\end{tabular}

Berdasarkan hasil uji kausalitas granger pada tabel 4.19 terdapat dua variabel yang mempunyai hubungan kausalitas dua arah yaitu variabel uang primer dan GWM Sekunder. Uang primer mempengaruhi GWM Sekunder, begitu juga GWM Sekunder mempengaruhi uang primer. Sedangkan variabel yang lain, hanya memiliki hubungan kausalitas satu arah dan terdapat variabel lain yang tidak memiliki hubungan kausalitas dalam lampiran 6, Variabel yang memiliki hubungan kausalitas satu arah yaitu inflasi mempengaruhi GWM Primer dan GWM Sekunder tetapi tidak sebaliknya. Nilai tukar mempengaruhi uang primer tetapi tidak sebaliknya. Kemudian, GWM Valas mempengaruhi uang primer tetapi tidak sebaliknya.

\section{KESIMPULAN}

Berdasarkan estimasi VECM yang diperjelas lebih lanjut dengan Impulse Response Function, instrumen kebijakan moneter dapat mencapai stabilitas harga tetapi membutuhkan waktu yang lebih lama dibanding kebijakan makroprudensial dalam mencapai stabilitas sistem keuangan yang diproksikan dengan stabilitas nilai tukar. Sedangkan instrumen kebijakan makroprudensial cukup efektif dalam menjaga 
volatilitas nilai tukar dan stabilitas harga. Hasil ini sesuai dengan latar belakang dirumuskannya kebijakan makroprudensial karena kebijakan moneter tidak dapat mencapai stabilitas sistem keuangan secara sendiri, sehingga bauran antara kebijakan moneter dan makroprudensial diperlukan untuk menjaga stabilitas harga dan stabilitas sistem keuangan.

Lebih lanjut, respon volatilitas inflasi dan volatilitas nilai tukar terhadap shock kebijakan moneter dan makroprudensial menuju pada keseimbangan baru tidak kembali pada keseimbangan awal seperti sebelum shock kebijakan. Suku bunga SBI mampu mencapai stabilitas harga pada kuartal ke-21 dan mencapai stabilitas nilai tukar pada kuartal ke-42. Uang Primer mampu mencapai stabilitas harga pada kuartal ke-35 dan mencapai stabilitas nilai tukar pada kuartal ke-45. Giro Wajib Minimum Primer mencapai stabilitas harga pada kuartal ke-27 dan mencapai stabilitas nilai tukar pada kuartal ke-28. Giro Wajib Minimum Sekunder mampu mencapai stabilitas harga pada kuartal ke-29 dan mencapai stabilitas nilai tukar pada kuartal ke-34. Giro Wajib Minimum Valuta Asing mampu mencapai stabilitas harga pada kuartal ke-33 dan mencapai stabilitas nilai tukar pada kuartal ke-21. Loan to Value mampu mencapai stabilitas harga pada kuartal ke-27 dan mencapai stabilitas nilai tukar pada kuartal ke-24. Terdapat hubungan kausalitas dua arah antara uang primer dengan GWM Sekunder. Tidak terdapat hubungan kausalitas antara inflasi dengan nilai tukar.

\section{UCAPAN TERIMA KASIH/ ACKNOWLEDGEMENT}

Penulis mengucapkan terima kasih kepada Bank Indonesia Institute yang telah membiayai penelitian ini melalui Program Bantuan Penelitian Bank Indonesia 2018.

\section{DAFTAR PUSTAKA}

Akinci, O., \& Olmstead-rumsey, J. 2015. How Effective are Macroprudential Policies? An Empirical Investigation Board of Governors of the Federal Reserve System, (1136).

Amrini, Y., Aimon, H., \& Syofyan, E. 2012. Analisis Pengaruh Kebijakan Moneter Terhadap Inflasi dan Perekonomian di Indonesia. Buletin Ekonomi Moneter Dan Perbankan, (1), 1-29.

Bank Indonesia. 2016. Mengupas Kebijakan Makroprudensial.

Chen, J., Columba, F., Beaumont, C., Berger, H., Canova, F., Finocchiaro, D., ... Rabanal, P. 2016. Macroprudential and Monetary Policy Interactions in a DSGE Model for Sweden Macroprudential and Monetary Policy Interactions in a DSGE Model for Sweden Authorized for Distribution.

Dumičić, M. 2017. Effectiveness of Macroprudential Policies in Central and Eastern European Countries.

FSB, BIS, \& IMF. 2009. Report to the G-20 Finance Ministers and Central Bank Governors: Guidance to Assess the Systemic Importance of Financial Institutions, Markets and Instruments: Initial Considerations. Report to the G20 Finance Ministers and Central Bank Governors, (Oktober), 1-27.

International Monetary Fund. 2013. The Interaction of Monetary and Macroprutential Policies. IMF Policy Papers.

Park, Y. C. 2011. The Role of Macroprudential Policy for Financial Stability in East 
Asia's Emerging Economies. Asian Development Bank Institutuse Working Paper Series, (284).

Purnawan, M. E., \& Nasir, M. A. 2015. The Role of Macroprudential Policy To

Manage Exchange Rate Volatility, Excess Banking Liquidity, and Credits. Buletin Ekonomi Moneter Dan Perbankan, 18(1), 21. https://doi.org/10.21098/bemp.v18i1.511

Simorangkir, I. 2004. Sistem dan Kebijakan Nilai Tukar. In Seri Kebanksentralan (12th ed., p. 48). Jakarta: Bank Indonesia.

Uysal, M. European C. B. 2016. Financial Stability and Macroprudential Policy, (9), 349-364.

Warjiyo, P. 2010. Bauran Kebijakan Bank Sentral: Konsepsi Pokok dan Pengalaman. Jakarta.

Warjiyo, P., \& Juhro, S. M. 2016. Kebijakan Bank Sentral Teori dan Praktik. Rajawali Pers.

Wimanda, R. E., Maryaningsih, N., Nurliana, L., \& Satyanugroho, R. 2014. Evaluasi Transmisi Bauran Kebijakan Bank Indonesia.

Wimanda, R. E., Permata, M. I., Bathaluddin, M. B., \& Wibowo, W. A. 2012. Studi Kebijakan Makroprudensial Di Indonesia: Evaluasi dan Analisa Integrasi Kebijakan Bank Indonesia. Bank Indonesia Working Paper (Vol. 11) 